\title{
Absence of Free-Cylindrospermopsin Bioconcentration in Water Thyme (Hydrilla verticillata)
}

S. H White ${ }^{1}$, L. J. Duivenvoorden ${ }^{1}$, L. D. Fabbro ${ }^{1}$

${ }^{1}$ Freshwater Ecology Group, Centre for Environmental Management Central Queensland University, Bruce Highway, Rockhampton.

Correspondence to: S. H. White

PH (07) 49309647

FAX (07) 49309209

Emails.white@cqu.edu.au 
Cylindrospermopsin (CYN) is a blue-green algal toxin first isolated and identified in 1992 (Ohtani et al. 1992). CYN is produced by several blue-green algae including Cylindrospermopsis raciborskii, Umezakia natans, Aphanizomenon ovalisporum, Anabaena bergii var limnetica and Raphidiopsis curvata (Li et al. 2001; Schembrii et al. 2001; Shaw et al. 1999; Stirling and Quilliam 2001). CYN studies are becoming increasingly important: this algal toxin remains one of the least well understood, despite compelling evidence for widespread environmental and human health risk. Furthermore, C. raciborskii, the most common producer of CYN, is a highly adaptive and invasive species being commonly reported from blooms worldwide (Briand et al. 2004; Padisák 1997).

CYN exerts a wide range of toxic effects on plants and animals. In the wellpublicized 'Palm Island Mystery Disease' of 1979, 138 children and 10 adults were hospitalised suffering acute gastroenteritis following CYN ingestion (Byth 1980; Griffiths and Saker 2003). General modes of action for CYN include cytotoxicity and hepatotoxicity, however inhibition of protein synthesis is the primary mechanism (Chong et al. 2002; Hawkins et al. 1985). Inhibition of glutathione synthesis has also been closely studied (Runnegar et al. 1995; 1994). Other lesserknown mechanisms include implications for the inhibition of molluscan neurones (Kiss et al. 2002), and strong evidence for cardiotoxicity, genotoxicity, tumour promotion and carcinogenicity (Bernard et al. 2003; Falconer and Humpage 2001; Ohtani et al. 1992; Shen et al. 2002).

Despite the likelihood for CYN's protein synthesis inhibition to be as equally applicable to primary producers as to animals, to date, only two studies have examined CYN toxicity on plant species. Neither study examined aquatic macrophytes. Vasas et al. (2002) demonstrated the inhibitory effects of CYN on the metabolism of Sinapis mustard seedlings, with $50 \%$ growth reduction apparent at $18.2 \mu \mathrm{g} \mathrm{ml}^{-1}$. Most recently, Metcalf et al. (2004) demonstrated reduced pollen germination in tobacco plants following CYN exposure between $5-1000 \mu \mathrm{g} \mathrm{ml}^{-1}$.

Only two studies have investigated the potential for CYN to bioaccumulate; again, no studies have involved plants. However, the potential for bioaccumulation of algal toxins is particularly significant: the occurrence of direct lethal and sublethal toxicities associated with exposure may increase in the presence of high toxin 
concentrations which result from bioaccumulation. Furthermore, there are implications for transfer of toxins throughout aquatic food chains, and possibly, contamination of human food sources.

Toxin uptake sources in affected aquatic ecosystems include both intracellular (cellbound) and extracellular (lysed, dissolved) toxins, while potential uptake routes are represented by dermal exposure, drinking of aqueous concentrations and oral consumption of suspended particles. Toxin accumulation risk in aquatic plants is solely represented by uptake of the extracellular fraction via the plant cell walls, as no consumption of algal cells takes place. Hence, in this paper, the process of toxin accumulation into plant tissues will be referred to as bioconcentration. This is consistent with the definition that bioconcentration is a special case of bioaccumulation that refers to uptake from toxins available from the water column, usually via epithelial tissues or in drinking water (Hall 2003).

Despite plants being at risk only from extracellular toxin, CYN uptake potential remains high, as most available surface area is in direct contact with toxins in the water column, and because CYN in both natural blooms and culture environments may be predominated by the extracellular, rather than intracellular, toxin fraction, depending on bloom age (Griffiths and Saker 2003; Hawkins et al. 2001).

Detection of CYN using liquid chromatography and tandem mass spectrometry (LC/MS/MS) is currently the method of choice (Nicholson and Burch 2001). However, an important limitation of current CYN studies, particularly for bioaccumulation work, is the inability of current analytical techniques to detect enzymatically-bound CYN within the cells of animals and plants. CYN may bind to such tissues because of its structural features (Duy et al. 2000), and because similar problems have been experienced with detection of another cyanotoxin, microcystin (Kankaanpää et al. 2002; Williams et al. 1997). This is problematic as the concentrations of CYN within aquatic organisms may be underestimated, as chemical detection is suitable only for unbound (free) CYN. Hence, this paper examines only free-CYN bioconcentration in the rooted, submersed aquatic macrophyte Hydrilla verticillata, using environmentally realistic CYN test concentrations.

\section{MATERIALS AND METHODS}

Hydrilla verticillata (1.f. Royle) was obtained from a private dam in Cawarral, Central Queensland and from an ornamental pond on the CQU campus. Neither of these collection points are known to experience blooms of Cylindrospermopsis raciborskii. Plants were washed thoroughly in tap water to remove epiphytic growth and other aquatic biota, and cultured under experimental conditions for a least one week prior to commencement of tests.

Cylindrospermopsin (CYN) was obtained from cultures of Cylindrospermopsis raciborskii (strains CQU-FR001 and -FR002) grown in ASM-1 media buffered to $\mathrm{pH} 7.8$ (Gorham et al. 1964). Culturing took place in glass Schott bottles in either a controlled-temperature room $\left(25 \pm 2^{0} \mathrm{C}\right.$, continuous light at approximately $6 \mu \mathrm{Em}^{-2}$ 
$\mathrm{s}^{-1}$ ) or on open laboratory shelves (approximately $4-5 \mu \mathrm{Em}^{-2} \mathrm{~s}^{-1}$ ).

Following initial range-finding tests, two definitive bioconcentration trials were conducted, along with one further trial to examine toxin depuration in $H$. verticillata. All trials took the form of semi-static renewal tests. Test sections of $H$. verticillata were obtained by separating lateral stems of generally uniform size from mother plants: each fragment was comprised of an apical tip with no lateral stems or roots.

Definitive trials examined exposure to extracellular CYN at six treatment concentrations, namely $0,25,50,100,200$ and $400 \mu \mathrm{g} \mathrm{L}^{-1}$. Trials lasted 14 days and were conducted under a 12:12 light:dark photoperiod (illumination, approximately $75 \mu$ mols $\mathrm{m}^{-2} \mathrm{~s}^{-1}$ ) at $26 \pm 4^{0} \mathrm{C}$. Plants were harvested at days 7 and 14 . In the depuration trial, the CYN and deoxy-CYN (an analog of CYN) concentrations of tissues were studied after seven days exposure to $0,100,250,350$ and $500 \mu \mathrm{g} \mathrm{L}^{-1}$ extracellular CYN, and also after one further week in CYN-free media. The trial was performed under continuous light at $27 \pm 2{ }^{0} \mathrm{C}$.

All extracellular CYN test concentrations (150ml volume) were prepared by freezethawing pooled $C$. raciborskii cultures of known CYN toxicity (based on a single subsampling event), and diluting to the desired concentration using ASM-1 media. Controls used ASM-1 algal culturing media only. Test chambers were glass crystallisation dishes $(300 \mathrm{ml}$ capacity); these were covered with soda-glass watch glasses to minimise evaporation. Dishes were always randomly placed on the trial bench, and repositioned regularly, following renewal of test solutions. All treatments were prepared using six replicates $(n=3$ for each of two exposure intervals).

To minimise the effects of toxin degradation over the trial period, test volumes (including controls) were renewed by half at three-day intervals, using $75 \mathrm{ml}$ of freshly prepared extracellular CYN solution. The displaced solutions were reserved, pooled within treatments and two samples randomly selected from each trial for analysis of CYN content (see below). Test chambers were measured for $\mathrm{pH}$ (TPS LC80A) and conductivity (TPS LC84) prior to solution renewal throughout all trials.

All plant samples from the definitive trials and selected samples from the depuration trial were analysed for free-CYN concentration. Following harvest, plants were rinsed with approximately $200 \mathrm{~mL}$ distilled water and blotted dry using paper towels. Samples were weighed (fresh weight, to $0.01 \mathrm{~g}$ ), frozen and freeze-dried (approximately 48hr, Virtis Sentry freeze-drier with Alcatel vacuum pump). Following re-weighing, samples were sent to the Queensland Health Scientific Service (QHSS, Brisbane) for analysis. Here, five $\mathrm{ml}$ of HPLC grade water was added to each sample, which was then homogenised at 24,000 rpm for approximately 1 min (Ultra Turrax homogeniser, IKA Works, Asia). The homogenate was allowed to settle before $1.5 \mathrm{ml}$ of supernatant was filtered through a 0.45 micron filter (Millex- HV, Millipore Corp., Bedford, MA) into a sample vial. 
Non-enzymatically bound cylindrospermopsin (free-CYN) was determined from both plant and water samples (e.g., treatment concentrations and original cultures) using HPLC/Electrospray/MS/MS [AB/Sciex API 300 mass spectrometer, Applied Biosystems, Concord, On. Canada, equipped with a turbo-ionspray interface coupled to a Shimadzu SCL-10Avp HPLC system, Shimadzu Corp., Kyoto, Japan] (Eaglesham et al. 1999). Positive samples were confirmed by both retention time (6.13 minutes) and by comparing transition intensity ratios between the sample and an appropriate concentration standard from the same run. The limit of detection for this method is $<200 \mathrm{ng} \mathrm{L}^{-1}$ for a $120 \mu \mathrm{l}$ injection volume (equivalent to 1.0 nanograms in $5 \mathrm{ml}$ ). One sample per batch was run in duplicate, in addition to a blank and control sample. This method generally gives $95 \%$ confidence limits of $\pm 13 \%$ as determined from controls run with each sample batch (G. K. Eaglesham, personal communication). Spike recoveries for $5 \mathrm{ml}$ homogenate spiked with CYN averaged $97.5 \%$ at $3.2 \mu \mathrm{g} \mathrm{L}^{-1}$ and $90 \%$ at $6.5 \mu \mathrm{gL}^{-1}$. Samples from the second definitive trial were also analysed for deoxy-CYN content (retention time, 6.63 minutes).

As the standard deviation of some replicates was zero, preferred statistical analyses (analysis of variance) could not be conducted on the collected data.

\section{RESULTS AND DISCUSSION}

A maximum of $176 \mathrm{ng}$ free-CYN g ${ }^{-1}$ freeze-dried tissue was recorded from $H$. verticillata in the definitive trials (Figure $1 \mathrm{a}, \mathrm{b}$ ). Based on a regression equation calculated from the fresh and freeze-dried data from both definitive trials, this was roughly equivalent to $15 \mathrm{ng}$ free-CYN g${ }^{-1}$ fresh weight $\left(\mathrm{y}=0.3823+(0.0825 \mathrm{x}) ; \mathrm{r}^{2}=\right.$ 0.9140 ; SigmaStat 3.0). There was no evidence to indicate free-CYN bioaccumulation had occurred: maximum tissue concentrations did not exceed exposure concentrations. That is, assuming 1 gram of plant tissue is equivalent to $1 \mathrm{~mL}$ of water; $15 \mathrm{ng} \mathrm{g}^{-1}$ tissue concentrations equates to only $15 \mu \mathrm{g} \mathrm{L}^{-1}$ media concentration. The average bioconcentration factor (tissue concentration divided by exposure concentration) for both definitive trials was only 0.045. In contrast, bioaccumulation is indicated by bioconcentration factors $>1$.

Deoxy-CYN concentrations were similarly low, peaking at approximately $160 \mathrm{ng} \mathrm{g}^{-1}$ freeze-dried tissue (Figure 2), roughly equivalent to $15 \mathrm{ng} \mathrm{g}^{-1}$ fresh weight ( $\mathrm{y}=$ $\left.0.1208+(0.0908 \mathrm{x}) ; \mathrm{r}^{2}=0.9517\right)$. The bioconcentration factor could not be calculated as deoxy-CYN exposure concentrations were unknown.

Despite the lack of bioaccumulation, there was a trend for plants in high-level CYN exposure concentrations ( $100 \mu \mathrm{g} \mathrm{L}{ }^{-1}$ or above) to record the highest tissue toxins. In contrast, exposure concentrations of $50 \mu \mathrm{g} \mathrm{L}^{-1}$ or below resulted in little or no free$\mathrm{CYN}$ in the tissues. This also occurred during the exposure phase of the depuration trial, although little or no free-CYN was present by the end of the depuration phase (Figure 1c). Other experimental work with CYN and the floating duckweed $S$. oligorrhiza has indicated that any detected free-CYN is likely to represent toxin adsorbed to the cell wall of $H$. verticillata, rather than toxin that has been taken up to become truly intracellular (White et al. unpublished data). In particular, CYN 
values recorded from the depuration trial are consistent with adsorption and 'rinsing' of toxins from the plant surface area.

Test solution conductivity values ranged from $210-770 \mu \mathrm{S} \mathrm{cm} \mathrm{cm}^{-1}$ over the trial periods. Higher values recorded towards the end of trial periods probably resulted from evaporative concentration. High test solution $\mathrm{pH}$ values ( $>9.0$ units) were also recorded during trials, particularly in the higher CYN-concentration treatments and towards the end of the exposure periods. High $\mathrm{pH}$ values may result from the original culture banks used to prepare treatment solutions: C. raciborskii cultures of similar age to those used in the trials have since had $\mathrm{pH}$ values measured between 9.3 - 9.7. Increases in $\mathrm{pH}$ may have also resulted from photosynthetic activity during exposure. Since elevated $\mathrm{pH}$ values are common in naturally occurring blooms no attempt was made to buffer $\mathrm{pH}$ during trials.

Declines in CYN concentration were experienced during trials (Table 1). Current OECD ecotoxicity guidelines stipulate that test concentrations should not vary by $> \pm 20 \%$ (OECD 2000) although such guidelines typically relate to inert toxicants (e.g., pesticides, heavy metals). Subsequent laboratory experimentation has indicated that preparing treatments based on a single CYN value for culture strength (as done for these trials) may inaccurately represent true CYN content. Increased accuracy may be achieved by increasing the number of determinations of original culture strength. CYN decomposition may also have occurred during the trial: although previous work indicates a long half-life for CYN (Chiswell et al. 1999), the effect of the elevated $\mathrm{pH}$ values in accelerating decomposition is unknown. Detection of trace CYN concentrations after the depuration phase may represent CYN introduced by association with $H$. verticillata, as plant material was not rinsed before transfer into CYN-free media.

Table 1. Extracellular CYN concentrations of two randomly chosen treatment solutions from each trial. Values indicate the CYN concentration in three pooled replicates of test solution.

\begin{tabular}{ccccc}
\hline $\begin{array}{c}\text { Trial Type } \\
\text { (Number) }\end{array}$ & $\begin{array}{c}\text { Days since } \\
\text { half-solution } \\
\text { replacement }\end{array}$ & $\begin{array}{c}\text { Prepared } \\
\text { Concentration } \\
\left(\mu \mathrm{g} \mathrm{L}^{-1} \mathrm{CYN}\right)\end{array}$ & $\begin{array}{c}\text { Actual } \\
\text { Concentration } \\
\left(\mu \mathrm{g} \mathrm{L}^{-1} \mathrm{CYN}\right)\end{array}$ & $\begin{array}{c}\text { Percent (\%) } \\
\text { Remaining }\end{array}$ \\
\hline Definitive 1 & 1 & 50 & 41.2 & 82 \\
Definitive 1 & 2 & 50 & 43.3 & 87 \\
Definitive 2 & 2 & 50 & 32 & 64 \\
Definitive 2 & 5 & $400^{\mathrm{a}}$ & $138^{\mathrm{a}}$ & $35^{\mathrm{a}}$ \\
Depuration & 1 & $250^{\mathrm{b}}$ & $229^{\mathrm{b}}$ & $92^{\mathrm{b}}$ \\
Depuration & 2 & $0^{\mathrm{c}}$ & $5^{\mathrm{c}}$ & $\mathrm{NA}^{\mathrm{c}}$ \\
\hline
\end{tabular}

a - Last solution renewal missed due to lack of available toxin

b - Exposure phase

c - Depuration phase

NA - Not applicable 


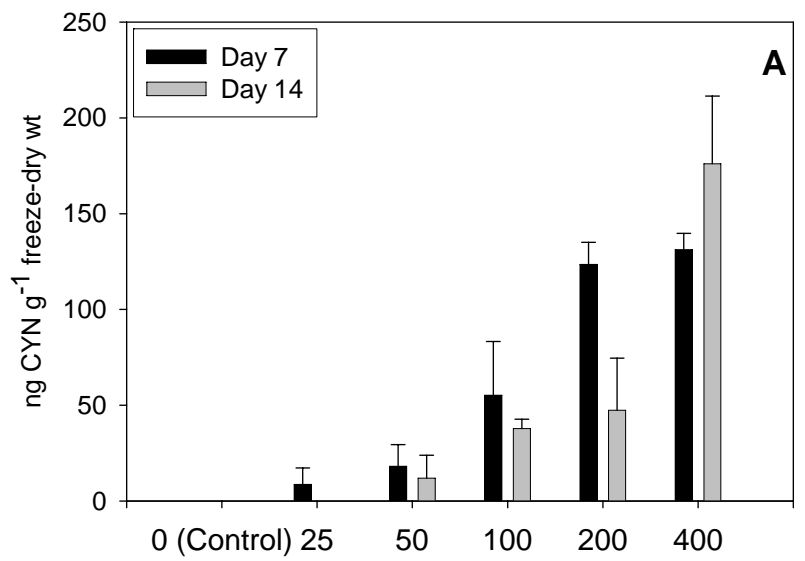

Treatment concentration ( $\mu \mathrm{g} \mathrm{L}^{-1}$ extracellular $\mathrm{CYN}$ )

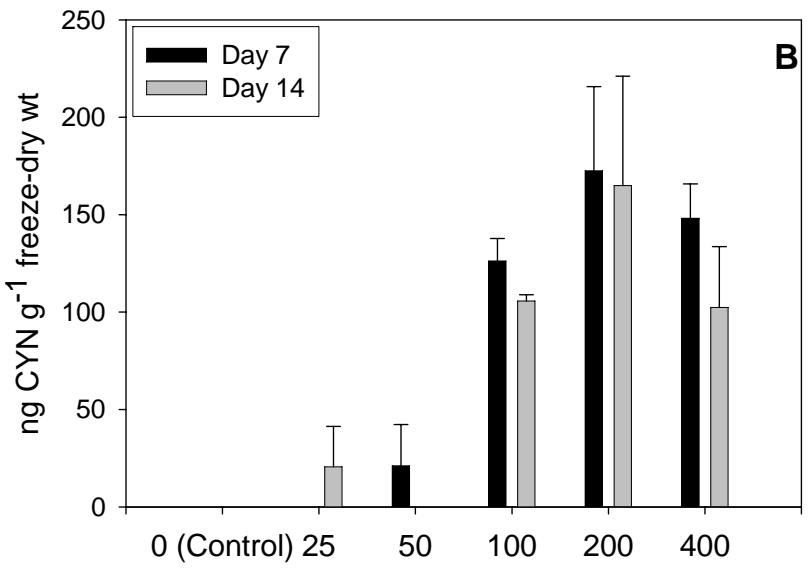

Treatment concentration ( $\mu \mathrm{g} \mathrm{L}^{-1}$ extracellular $\mathrm{CYN}$ )

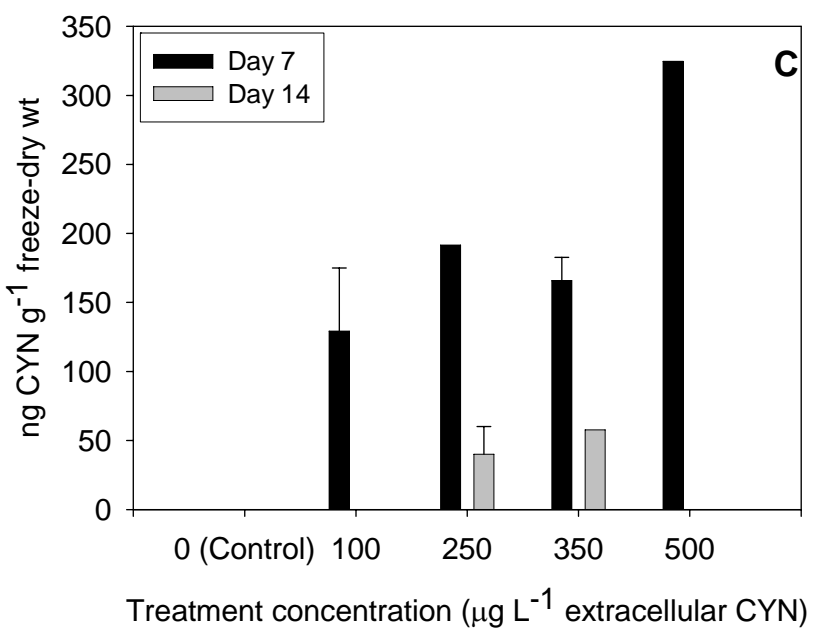

Figure 1. Free-CYN concentration in $H$. verticillata tissues (A) Definitive trial 1. (B) Definitive trial 2. (C) Depuration trial. Bars depict the average of three replicates, except in (C) where only selected samples were tested. Error bars depict standard error. 


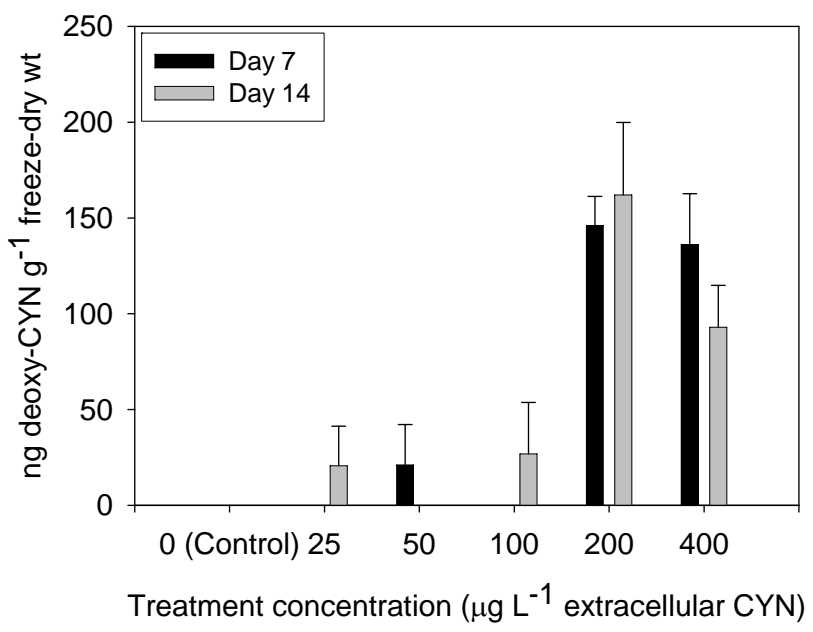

Figure 2. Free deoxy-CYN concentration in $H$. verticillata tissues from definitive trial 2. Bars depict the average of three replicates, error bars depict standard error.

The lack of free-CYN bioconcentration in $H$. verticillata indicates one of three possibilities. Firstly, $H$. verticillata may be incapable of extracellular-CYN uptake, and is thus not able to receive a 'bioavailable' CYN dose. Secondly, toxin uptake may be possible, however intracellular toxin could then be transported out of the cell at the same rate at which it enters, resulting in no net accumulation. Lastly, intracellular CYN may become enzymatically bound, modified or metabolised within plant tissues and hence is not able to be detected via HPLC. The latter problem has been demonstrated to occur with another algal toxin, microcystin, making extraction and detection difficult (Kankaanpää et al. 2002; Williams et al. 1997). High levels of bioaccumulated free-CYN have been recorded from aquatic organisms other than plants (Saker and Eaglesham 1999; Saker et al. 2004). Pflugmacher (2002) theorised that microcystin, at least, could be taken up by plant chloroplasts, to later become non-enzymatically bound or enzymatically conjugated to GSH. This may also be true of CYN, thus explaining the apparent lack of bioconcentration in plants, despite high levels being recorded from animals. The capability for plants to transport CYN out of cells is unknown.

This is the first study to demonstrate a lack of free-CYN biconcentration in an aquatic macrophyte. In the absence of an improved analytical method for detection of bound or modified CYN, radiolabelling or enzyme-marking studies may provide further information regarding the uptake pathway(s) and possible bioaccumulation of total CYN and its metabolites in aquatic macrophytes.

Acknowledgements The authors gratefully acknowledge financial support from Nebo Shire Council (Lake Elphinstone Alliance), the CQU Centre for Environmental Management, Research Training Scheme funds, and an Australian Postgraduate Award. Geoff Eaglesham (QHSS) is particularly thanked for his work with CYN analyses. 


\section{REFERENCES}

Bernard C, Harvey M, Biré R, Krys S, Fontaine JJ (2003) Toxicological comparison of diverse Cylindrospermopsis raciborskii strains: Evidence of liver damage caused by a French C. raciborskii strain. Environ Toxicol 18:176-186

Briand JF, Leboulanger C, Humbert J-F, Bernard C, Dufour P (2004) Cylindrospermopsis raciborskii (Cyanobacteria) invasion at mid-latitudes: selection; wide physiological tolerance, or global warming? J Phycol 40:231-238

Byth S (1980) Palm Island mystery disease. Med J Australia 2:40-42

Chiswell RK, Shaw GR, Eaglesham G, Smith MJ, Norris KR, Seawright AA, Moore MR (1999) Stability of cylindrospermopsin, the toxin from the cyanobacterium, Cylindrospermopsis raciborskii: Effect of $\mathrm{pH}$, temperature and sunlight on decomposition. Environ Toxicol 14:155-161

Chong MWK, Wong BSF, Lam PKS, Shaw GR, Seawright AA (2002) Toxicity and uptake mechanism of cylindrospermopsin and lophyrotomin in primary rat hepatocytes. Toxicon 40:205-211

Duy TN, Lam PKS, Shaw GR, Connell DW (2000) Toxicology and risk assessment of freshwater cyanobacterial (Blue-Green Algal) toxins in water. Rev Environ Contam Toxicol 163:113-186

Eaglesham G, Norris KR, Shaw GR, Smith MJ, Chiswell RK, Davis BC, Neville GR, Seawright AA, Moore BS (1999) Use of HPLC-MS/MS to monitor cylindrospermopsin, a blue-green algal toxin, for public health purposes. Environ Toxicol 14:151-154

Falconer IR, Humpage AR (2001) Preliminary evidence for in vivo tumour initiation by oral administration of extracts of the blue green alga Cylindrospermopsis raciborskii containing the toxin cylindrospermopsin. Environ Toxicol 16:192195

Gorham PR, Mc Lachlan J, Hammer UT, Kim WK (1964) Isolation and culture of toxic strains of Anabaena flos-aquae (Lyngb.) de Breb. Verhandlungen. Int Vereinigung Theoret Angewandte Limnol 15:796-804

Griffiths DJ, Saker ML (2003) The Palm Island mystery disease 20 years on: A review of research on the cyanotoxin cylindrospermopsin. Environ Toxicol $18: 78-93$

Hall JE (2003) Bioconcentration, bioaccumulation, and biomagnification in Puget Sound biota: Assessing the ecological risk of chemical contaminants in Puget Sound. J Environ 1:1-19.

Hawkins PR, Putt E, Falconer IR, Humpage AR (2001) Phenotypical variation in a toxic strain of the phytoplankter, Cylindrospermopsis raciborskii (Nostocales, Cyanophyceae) during batch culture. Environ Toxicol 16:460-467

Hawkins PR, Runnegar MTC, Jackson ARB, Falconer IR (1985) Severe hepatotoxicity caused by the tropical cyanobacterium (blue-green alga) Cylindrospermopsis raciborskii (Woloszynska) Seenaya and Subba Raju isolated from a domestic water supply reservoir. Appl Environ Microbiol 50:1292-1295

Kankaanpää H, Vuorinen PJ, Sipiä V, Keinänen M (2002) Acute effects and bioccumulation of nodularin in sea trout (Salmo trutta m. trutta L.) exposed 
orally to Nodularia spumigena under laboratory conditions. Aquat Toxicol 61:155-168

Kiss T, Vehovsky Á, Hiripi L, Kovács M, Vörös L (2002) Membrane effects of toxins isolated from a cyanobacterium, Cylindrospermopsis raciborskii, on identified molluscan neurones. Comp Biochem Physiol C 131:167-176

Li R, Carmichael WW, Brittain S, Eaglesham G, Shaw G, Liu Y, Watanabe M (2001) First report of the cyanotoxins cylindrospermopsin and deoxycylindrospermopsin from Raphidiopsis curvata (Cyanobacteria). J Phycol 37: 1121-1126

Metcalf JS, Barakate A, Codd GA (2004) Inhibition of plant protein synthesis by the cyanobacterial hepatotoxin, cylindrospermopsin. FEMS Microbiol Lett 235:125129

Nicholson BC, Burch MD (2001) Evaluation of analytical methods for detection and quantification of cyanotoxins in relation to Australian drinking water guidelines. National Health and Medical Research Council of Australia/WSAA/CRC for Water Quality and Treatment, Canberra.

Ohtani I, Moore RE, Runnegar MTC (1992) Cylindrospermopsin: a potent hepatotoxin from the blue-green alga Cylindrospermopsis raciborskii. J Amer Chem Soc 114:7941-7942

OECD (Organisation for Economic Cooperation and Development) (2000). Guidance document on aquatic toxicity testing of difficult substances and mixtures. Organisation for Economic Cooperation and Development, Environmental Directorate, Paris

Padisák J (1997) Cylindrospermopsis raciborskii (Woloszynska) Seenayya et Subba Raju, an expanding highly adaptive cyanobacterium: worldwide distribution and review of its ecology. Archiv fuer Hydrobiol. Suppl 107 (Monographic Studies) 4:563-593

Pflugmacher S (2002) Possible allelopathic effects of cyanotoxins, with reference to microcystin-LR, in aquatic ecosystems. Environ Toxicol 17:407-413

Runnegar MT, Kong S, Zhong Y, Lu SC (1995) Inhibition of reduced glutathione synthesis by cyanobacterial alkaloid cylindrospermopsin in cultured rat hepatocytes. Biochem Pharmacol 49:219-225

Runnegar MT, Kong SM, Zhong YZ, Ge JL, Lu SC (1994) The role of glutathione in the toxicity of a novel cyanobacterial alkaloid cylindrospermopsin in cultured rat hepatocytes. Biochem Biophys Res Comm 201:235-241

Saker ML, Eaglesham GK (1999) The accumulation of cylindrospermopsin from the cyanobacterium Cylindrospermopsis raciborskii in tissues of the Redclaw crayfish Cherax quadricarinatus. Toxicon 37:1065-1077

Saker ML, Metcalf JS, Codd GA, Vasconcelos VM (2004) Accumulation and depuration of the cyanobacterial toxin cylindrospermopsin in the freshwater mussel Anodonta cygnea. Toxicon 43:185-194

Schembrii MA, Neilan BA, Saint CP (2001) Identification of genes implicated in toxin production in the cyanobacterium Cylindrospermopsis raciborskii. Environ Toxicol 16:413-421

Shaw G, Sufenik A, Livne A, Chiswell RK, Smith MJ, Seawright AA, Norris KR, Eaglesham G, Moore MR (1999) Blooms of the cylindrospermopsin containing cyanobacterium, Aphanizomenon ovalisporum (Forti) in newly constructed lakes, Queensland, Australia. Environ Toxicol14:167-177 
Shen X, Lam PKS, Shaw GR, Wickramasinghe W (2002) Genotoxicity investigation of a cyanobacterial toxin, cylindrospermopsin. Toxicon 40:14991501

Stirling DJ, Quilliam MA (2001) First report of the cyanobacterial toxin cylindrospermopsin in New Zealand. Toxicon 39:1219-1222

Vasas GA, Gáspár G, Surányi G, Batta G, Gyémánt M, M-Hamvas C, Máthé GI, Molnár E, Borbély G (2002). Capillary electrophorectic assay and purification of cylindrospermpsin, A cyanobacterial toxin from Aphanizomenon ovalisporum, by plant test (Blue-Green Sinapis Test). Anal Biochem 302: 95-103

Williams DE, Dawe SC, Kent ML, Andersen RJ, Craig M, Holmes CF (1997) Bioaccumulation and clearance of microcystins from salt water mussels, Mytilus edulis, and in vivo evidence for covalently bound microcystins in mussel tissues. Toxicon 35:1617-1625 